\title{
Macroeconomic Implications of the Monetary Policy Committee Recommendations: An IS-LM Framework
}

\author{
Khyati Kathuria ${ }^{1}$ and Pawan Whig ${ }^{2 *}$ \\ ${ }^{1}$ Assistant Professor, VIPS, GGSIPU, India \\ ${ }^{2}$ Dean Research, VIPS, GGSIPU, India \\ *Corresponding Author: Pawan Whig, Dean Research, VIPS, GGSIPU, India.
}

DOI: $10.31080 /$ ASAG.2020.04.0782
Received: December 04, 2019

Published: January 28, 2020

(C) All rights are reserved by Khyati

Kathuria and Pawan Whig.

\begin{abstract}
The paper aims to analyze the possible implications of the decisions taken by the Reserve Bank of India (RBI) in its monetary policy committee (MPC) meeting in the year 2019 for the Indian economy. The MPC is a committee of the Central Bank in India (RBI), headed by its Governor, which is entrusted with the task of fixing the benchmark policy interest rate (repo rate) to contain inflation within the specified target level. Throughout the year the MPC has reduced the policy repo rate and changed its stance from neutral to accommodative. The macroeconomic impact of such decisions has been analyzed in an IS-LM framework. The impact of the corporate tax cut done by the Finance Minister has also been analyzed using the IS-LM and AD-AS approach.
\end{abstract}

Keywords: Inflation; India; Interest Rate; IS-LM; MPC; RBI; Repo Rate

\section{Introduction}

The Monetary Policy Committee (MPC) is a committee of the Reserve bank of India (RBI) headed by its Governor. The MPC is entrusted with the task of fixing the benchmark policy repo rate to contain inflation within the required target level. As defined in Section 2 (iii) of the Reserve Bank of India Act, 1934 and constituted under sub-section (1) of section 45ZB of the same Act MPC with the aid and advice of his internal team and a technical advisory committee, has complete control over monetary policy decisions.

\section{Background}

MPC came up consequent to an agreement between Government and RBI to assign RBI the obligation for price stability and targeting. On $20^{\text {th }}$ February 2015 the Monetary Policy Framework Agreement was signed.

Successively, while unveiling the Union Budget for 2016-17 in the Parliament, the government projected for an amendment in the RBI Act, 1934 for setting up a Monetary Policy Committee (MPC). The amendment gave a statutory backing to the aforesaid Monetary
Policy Framework Agreement. According to the modification, the primary objective of the monetary policy will be to maintain price stability, while keeping in mind the objective of growth, and to meet the challenge of an increasingly complex economy was written in the preamble of the RBI Act. Thus, the modification provides a legal basis to the Monetary Policy Framework (MPF) and the MPC.

Suggestions for putting in place an MPC can be traced back to 2002 when the committee chaired by Y. V. Reddy counseled for an MPC to decide policy actions. Afterwards, in 2006 the Tarapore Committee, in 2007 the Percy Mistry Committee, in 2009 the Raghuram Rajan Committee and so in 2013, both the report of the Financial Sector Legislative Reforms Commission (FSLRC) and therefore the Dr. Urjit R. Patel (URP) Committee suggested to set up a MPC. Consistent with the URP Committee, "A worldwide movement towards a committee-based approach to decision making have been propelled with a view to bringing in greater transparency and accountability in India". 


\section{Objectives of the Study}

According to the Monetary Policy Framework Agreement, the RBI will be accountable for containing inflation targets at $4 \%$ (with a standard deviation of $2 \%$ ) specified to it by the Central Government in the medium term. For the purpose MPC will decide the changes to be created to the policy repo rate. Each Member of the Monetary Policy Committee will be required to write an announcement specifying the explanations for voting in favor of, or against the proposed resolution. Given the importance of the variables like inflation managed by the monetary policy committee the objective of the present study is to analyze the impact of decisions taken by MPC with respect to these variables like corporate tax cut, changes in the repo rate etc. Since not many papers have linked the impact of such moves by MPC to the theoretical framework in macroeconomics the present study aims to fill the gap by analyzing the impact of such decisions in a diagrammatic fashion using IS-LM and AD-AS approach.

\section{Composition}

The Central government constitutes the MPC via a notification in the Official Gazette. The RBI Governor (Chairperson), the RBI Deputy Governor in charge of monetary policy, one official nominated by the RBI Board and the remaining three members representing the Government of India together constitute the 6 members of the MPC.

The three central government nominees of the MPC will be appointed by the search cum selection committee and will hold office for a period of four years. They will not be eligible for re-appointment. At present the committee includes the following members:

- $\quad$ Dr. Chetan Ghate, Professor, Indian Statistical Institute;

- Dr. Pami Dua, Director, Delhi School of Economics;

- Dr. Ravindra H. Dholakia, former Professor, Indian Institute of Management, Ahmedabad;

- Dr. Michael Debabrata Patra, Executive Director (the officer of the Reserve Bank nominated by the Central Board under Section 45ZB(2)(c) of the Reserve Bank of India Act, 1934);

- Dr. Viral V. Acharya, Deputy Governor in charge of monetary policy;

- Shri Shaktikanta Das, Governor.

\section{Decision making at MPC}

The decisions taken by MPC are based on a majority vote. The RBI governor will have the second or casting vote in case of a tie. The decision of the MPC would be binding on the RBI. According to the Reserve Bank of India Act, 1934, the RBI shall organize at least four meetings of the MPC in a year and the meeting schedule of the MPC for a year shall be published at least one week before the first meeting in that year. Accordingly, it has been decided that the MPC will meet six times during 2019-20 as indicated below:

First Bi-monthly Monetary Policy Statement for 2019-20: April 2 to 4,2019

Second Bi-monthly Monetary Policy Statement for 2019-20: June 3, 4 and 6, 2019

Third Bi-monthly Monetary Policy Statement for 2019-20: August 5 to 7,2019

Fourth Bi-monthly Monetary Policy Statement for 2019-20: October 1, 3 and 4, 2019

Fifth Bi-monthly Monetary Policy Statement for 2019-20: December 3 to 5,2019

Sixth Bi-monthly Monetary Policy Statement for 2019-20: February 4 to 6,2020 .

Source: RBI

The First Bi-monthly Monetary Policy committee meeting $\left(16^{\text {th }}\right.$ MPC meeting) was held from April 2 to 4, 2019 at the Reserve Bank of India, Mumbai. On the basis of an assessment of the current and evolving macroeconomic situation, the Monetary Policy Committee (MPC) decided to:

- $\quad$ Policy repo rate under the liquidity adjustment facility (LAF) to be reduced by 25 basis points to 6.0 percent from 6.25 percent with immediate effect.

- The reverse repo rate under the LAF stood adjusted to 5.75 percent, and the marginal standing facility (MSF) rate and the Bank Rate to 6.25 percent.

- Maintaining the neutral monetary policy stance was also decided. 
These decisions were in harmony with the objective of achieving the medium-term target for consumer price index (CPI) inflation of 4 percent within a band of $+/-2$ percent while supporting growth.

What caused these decisions??

- Economic activity had been losing pace, globally.

- Inflation continued to stay low in several key emerging market economies due to slow down in the global growth and stable or falling commodity prices. Gold and crude oil prices also weakened.

- Domestically, due to slowing consumption economic activity there was deceleration for the third consecutive quarter in Q3:2018-19.

- On the supply side, GVA growth slowed down due to a deceleration in agriculture output.

- Slowdown in manufacturing component of the index of industrial production (IIP) growth to 1.3 percent in January 2019.

- During February 1-6, 2019, systemic liquidity moved into deficit from February 7 - March 31.

- Due to exports of petroleum products decelerating in response to a fall in international crude oil prices export growth remained weak in January and February 2019.

\section{Results}

The above decisions were taken by the MPC of RBI for inflation management had the following impact. Due to a repo rate cut (the rate at which RBI gives loans to the commercial banks) banks were left with more money in their hands which enabled them to give loans thus encouraging credit creation. Thus, the move favored the borrowers who were able to borrow at a low rate of interest. But the move was against the depositors who faced a decline in the interest rate they earned on their deposits like FD's.

Diagrammatically, as shown in Figure 1 initial equilibrium in the goods market and the money market is at point a (with output $Y_{1}$ ) i.e. at the intersection of the IS and the LM curves.

An increase in the money supply via a repo rate cut shifted the LM curve to the right from $\mathrm{LM}_{1}$ to $\mathrm{LM}_{2}$ (Figure 1). This rightward shift led to a fall in the interest rate and an increase in the output from $Y_{1}$ to $Y_{2}$ as shown in the movement from pt. A to B (Figure 1). But since the repo rate cut is against the depositors it discouraged the savings rate which led to a leftward shift in the IS curve from

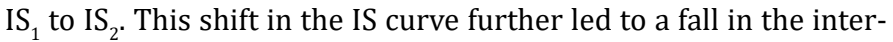
est rate but the output returned to the pre-change output levels thereby indicating that money is neutral in the medium term which means an increase in money supply will not affect any real vari-

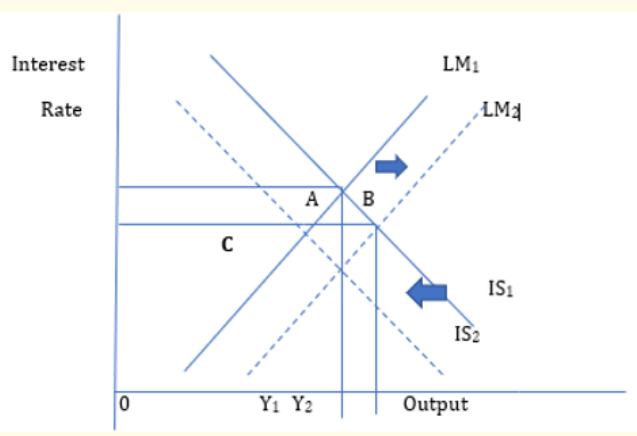

Figure 1: Impact of a Repo rate cut in IS-LM framework.

ables like real money supply, output, etc.

In terms $\mathrm{AD}-\mathrm{AS}$ the initial equilibrium is at point $\mathrm{A}^{\prime}$ (Figure 2). However, due to a shift in the LM curve in response to the repo rate cut the interest rate falls and investment (I) increases. A rise in I causes the aggregate demand curve to shift out to the right from $A D_{1}$ to $A D_{2}$ as a result of which output increases from $Y_{1}$ to $Y_{2}$ and the price level also increases and the economy reaches point B'. This price rise will cause the real money supply to remain unchanged. However, due to a decline in the savings rate in response to the repo rate cut the $\mathrm{AD}$ curve will shift back to its original position so that the price and output will remain unchanged again reflecting the neutrality of money.

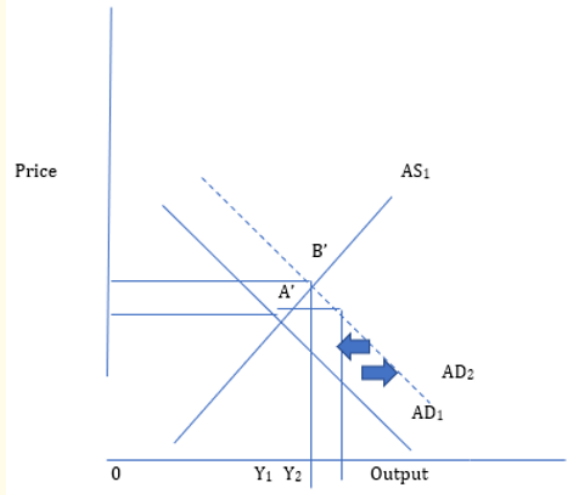

Figure 2: Impact of a Repo rate cut in AD-AS framework. 
The Second bi-monthly (seventeenth meeting) of the MPC was held during June 3, 4 and 62019 in Mumbai. On the basis of an assessment of the current and evolving macroeconomic situation, MPC at its meeting decided to:

- $\quad$ Reduce the policy repo rate under the LAF by 25 basis points to 5.75 percent from 6.0 percent with immediate effect.

- Consequently, the reverse repo rate under the LAF stood adjusted to 5.50 percent, and the MSF rate and the Bank Rate to 6.0 percent.

- It was also decided to change the stance of monetary policy from neutral to accommodative (means there is a possibility of further monetary easing in the months ahead).

- $\quad$ Likewise, the third bi-monthly Monetary Policy Statement, Monetary Policy Committee (MPC) at its meeting today decided to:

- $\quad$ Reduce the policy repo rate under the LAF by 35 basis points (bps) from 5.75 percent to 5.40 percent with immediate effect.

- Consequently, the reverse repo rate under the LAF stands revised to 5.15 percent, and the MSF rate and the Bank Rate to 5.65 percent.

- It was also decided to maintain the accommodative stance of monetary policy.

- The fourth bi-monthly Monetary Policy Statement the MPC at its meeting on October 4, 2019 decided to:

- $\quad$ Reduce the policy repo rate under the LAF by 25 basis points to 5.15 percent from 5.40 percent with immediate effect.

- Consequently, the reverse repo rate under the LAF stands reduced to 4.90 percent, and the MSF rate and the Bank Rate to 5.40 percent.

- It was also decided to continue with an accommodative stance as long as it is necessary to revive growth while ensuring that inflation remains within the target.

\section{Impact of the repo rate cut four times in a row}

It was seen that the full benefit of the cumulative back-to-back reduction in the repo rate was not passed on to the customers by the banks. It was also found that despite the rate cut the interest rate on bank loans climbed or remained constant rather than fall- ing. Banks cut their rates based on the cost of raising new funds which includes the cost of maintaining mandatory CRR, SLR, as well as their operating costs. They claim that the cost of funds has been high previously due to the high deposit rate and till the time it does not change immediately bank's lending rate will also not change much. Thus, need of the hour is to raise the transmission rate of the rate cut by RBI so that consumer spending is encouraged in this gloomy scenario, given the economic slowdown and declining consumption. The move will be a much-needed breather to the liquidity and consumption volatility problems within the Indian economy provided the banks reciprocate the rate cuts.

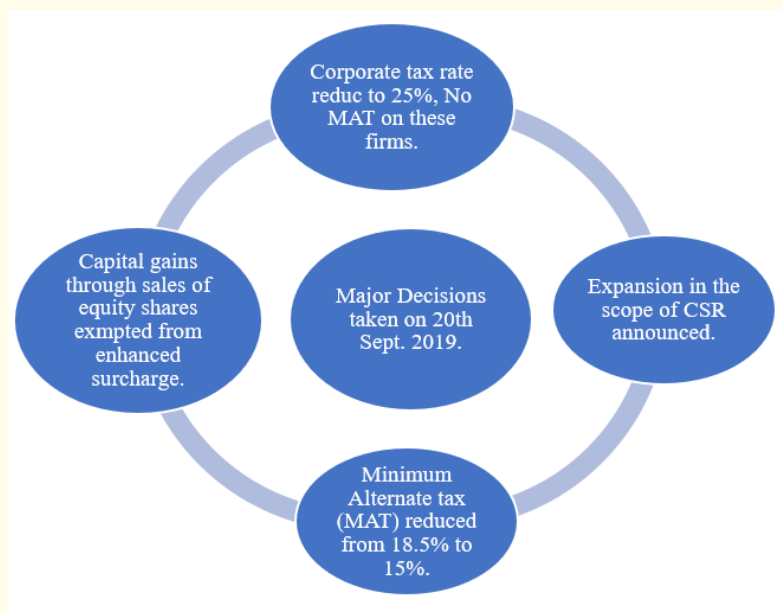

Figure a

Impact of the FM's bold move to supply $\mathbf{O}_{2}$ to the economy

It was expected that the above decisions will have both macro and microeconomic impacts on the economy.

Talking macroeconomically, as shown in Figure 3 initial equilibrium in the goods market and the money market is at point a (with output $Y_{1}$ ) i.e. at the intersection of the IS and the LM curves. Due to a decline in the corporate tax rate the IS curve shifts out to the right from IS to IS $_{2}$ and the interest rate increases to point $\mathrm{b}$. An increase in the interest rate will not solely boost domestic investment but will additionally encourage FDI and FII from the rest of the world. Given the trade war, the companies which wanted to exit China will look forward to investing in India. On the other hand, due to an increase in the interest rate demand for money decreases and 
LM curve shifts down to the right thus bringing the interest rate back to the initial equilibrium but at point $\mathrm{c}$ which corresponds to a higher level of output $\left(\mathrm{Y}_{3}\right)$.

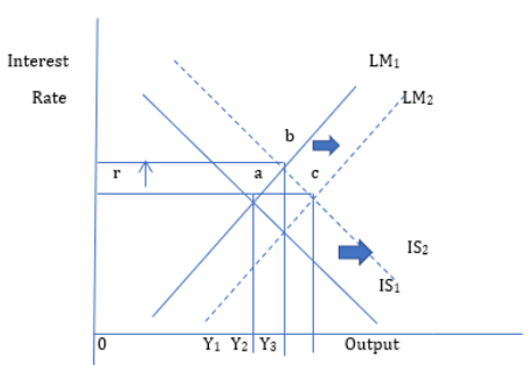

Figure 3: Impact of corporate tax cut in IS-LM framework.

In terms $\mathrm{AD}-\mathrm{AS}$ the initial equilibrium is at point a' (Figure 4). However, due to the shifts in the IS and LM curves the aggregate demand curve shifts out to the right from $A D_{1}$ to $A D_{2}$ as a result of which output increases from $Y_{1}$ to $Y_{2}$ and the price level also increases in the short run. The economy reaches point b' as supply cannot expand immediately. Increase in the price level and decline in the cost (due to a decline in the tax rate) will provide an incentive to the firms to increase supply and the AS curve shifts out to the right and final equilibrium is achieved at point $c^{\prime}$ which is at the initial price level in the long run but corresponds to a higher level of output. Thus, though due to the aforementioned decisions the economy will have to bear the consequence of high prices in the short run, in the long run, the initial equilibrium price will be achieved at a higher level of output thereby having an expansionary impact on the economy.

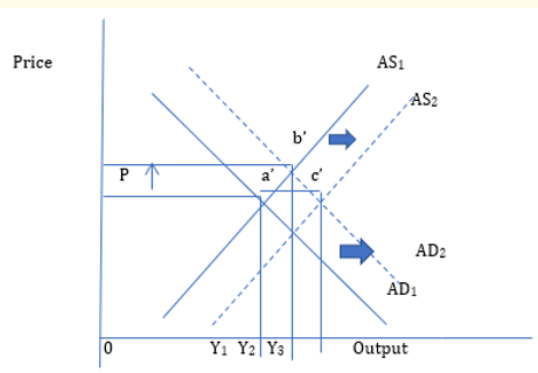

Figure 4: Impact of corporate tax cut in AD-AS framework.
In terms of microeconomy output expansion by the firms will increase the level of employment in the economy. The chain of effects is as: to expand output firms will require more labor so the demand for labor increases, increased dd leads to an increase in the bargaining power of workers and hence the wage rate. Thus, with an increase in both the prices and the wage rate the real wage rate remains constant but the economy achieves a higher level of output and employment in the long run.

Also, according to the lump sum principle (Snyder and Nicholson, $11^{\text {th }}$ ed.) corporate tax has the same impact as the lumpsum tax. A decline in the corporate tax leads to an increase in the utility higher than an equivalent decline in the per-unit tax.

But it was observed that taxes were not the real problem. The nature of the current slowdown is due to the weak consumer demand, there is no reason for the private companies then to invest more if their tax outflow decreases as, if the consumers are not spending in the first place due to high unemployment and diminishing wages, additional investments become risky. Also, given the placid demand corporate tax cut would not encourage the companies to increase production. Therefore, a more effective solution would be to inject liquidity directly by increasing the consumer's disposable incomes. Such a stimulus can also create new investment opportunities by rising consumer demand. Through the rate cut the companies will now get a larger share of profits and the economy is still on the slow lane [1-7].

\section{Conclusion}

The stance taken by the monetary policy committee have strong micro and macroeconomic impacts on the economy. Given that Indian economy had been losing pace in the global economy certain bold decisions were taken by the MPC and the Ministry of Finance in the year 2019 in the MPC meeting. Such decisions have a strong impact of the economy. The present study tried to study the impact by connecting it to the theoretical framework of macroeconomics in a diagrammatic fashion using IS-LM and AD-AS framework. It was found that though the welfare oriented the policies did not treat the actual disease the economy was suffering from that is the lacking consumer demand. As neither firm would raise the output in reaction to a tax cut if the consumers are not willing to spend. Therefore, it is suggested that the more effective solution would be to inject more liquidity by increasing the consumer's disposable income. 


\section{Bibliography}

1. Snyder CM., et al. "Microeconomic theory: Basic principles and extensions". South-Western Cengage Learning (2012): 488489.

2. "Reserve Bank of India". Reserve Bank of India, www.rbi.org. in/.

3. Blanchard OA., et al. Lectures on macroeconomics. MIT press (1989).

4. Samuelson PA and Scott A. Economics: an introductory analysis. New York: McGraw-Hill 715 (1967).

5. Branson WH. Macroeconomic determinants of real exchange rates (1981).

6. Dornbusch R and Edwards S. The macroeconomics of populism. In The macroeconomics of populism in Latin America. University of Chicago Press (1991): 7-13.

7. Froyen RT and Perez SJ. Macroeconomics: Theories and policies (No. 339 F7 2005). Macmillan (1990).

\section{Assets from publication with us}

- Prompt Acknowledgement after receiving the article

- Thorough Double blinded peer review

- Rapid Publication

- Issue of Publication Certificate

- High visibility of your Published work

Website: www.actascientific.com/

Submit Article: www.actascientific.com/submission.php Email us: editor@actascientific.com

Contact us: +919182824667 